\title{
ТАТАРЫН СЦЯПАН ХУСЕЙНАВІЧ АЛЕКСАНДРОВІЧ ЯК ПРАДСТАЎНІК БЕЛАРУСКАЙ КУЛЬТУРЫ
}

\section{С. У. ГРЫБАВА}

\section{Брэсикі дзяржаўны тэхнічны ўніверсітэт, г. Брэст, Беларусь}

Асоба беларускага татарына Сцяпана Хусейнавіча Александровіча заслугоўвае асаблівай увагі. 3' яўляючыся прадстаўніком нацыянальнай групы мясцовых татараў, ён шмат зрабіў для развіцця беларускай культуры як пісьменнік, літаратуразнаўца, крытык, краязнаўца.

Сцяпан Хусейнавіч Александровіч нарадзіўся 15 снежня 1921 г. у сям’і капыльскіх татараў. 31929 г. па 1939 г. вучыўся ў сярэдняй школе № 1, у верасні 1939 г. паступіў на філалагічны факультэт БДУ. Аднак у 1940 г. быў прызваны Капыльскім ваенкаматам на службу ў Чырвоную Армію. Напачатку Вялікай Айчыннай вайны знаходзіўся ў Іране. 16 мая 1942 г. ля старой крэпасці Енікале ён быў паранены падчас баявых дзеянняў, а праз тыдзень трапіў у палон. Апынуўся ў лагеры ваеннапалонных у Крывым Розе. «Мусульманская вера бацькоў уратавала яго, калі адзін з барачных фюрэраў ставіў яго да сцяны, істэрычна выдыхаючы ў твар: “Юдэ!!” Жыццё яму вярнуў працытаваны па памяці ўрывак з Кур'ана» [1, с. 19].

У жніўні 1942 г. С. Х. Александровіч уцёк з канцэнтрацыйнага лагера і пасля двухмесячнага блукання, прайшоўшы Украіну і Палессе, у в. Сярэднікі пад Слуцкам зваліўся 3 ног. Адзін чалавек злітаваўся і прывёз яго ледзь жывога ў Капыль. Было гэта ў кастрычніку 1942 г. Цяжкія лагерныя выпрабаванні i шлях дадому апісаны ім у амаль што дакументальнай аповесці «Далёкія зарніцы» [2]. Калі дабраўся да родных, як успамінае С. Х. Александровіч у сваёй кнізе «Кнігі і людзі. Даследаванні, архіўныя знаходкі, успаміны, эсэ», «пацягнуліся пакутлівыя дні дамашняга арышту. 3 хаты не пускала хвароба (з лагера прынёс працэс ў лёгкіх), баяўся і чужога вока. На легальнае становішча перайшоў канчаткова вясною 1943 г. 3 гэтага часу ў мяне ўжо наладзіліся сувязі з партызанамі, якім бацька вырабляў аўчыны і круціў сырамяць на збрую» [3].

На Капыльшчыне ён удзельнічаў у падполлі i супрацоўнічаў 3 партызанамі. Знаходзячыся на службе ў акупантаў, у паліцыі, перадаваў партызанам паролі, здабываў зброю і боепрыпасы. Ён, дарэчы, кіраваў працай падпольшчыкаў, якія служылі ў паліцыі [4, арк. 6]. Ёсць звесткі аб тым, што С. Х. Александровіч прымаў удзел у дзвюх баявых аперацыях дыверсійнай групы, у тым ліку ў аперацыі ў ноч з 29 лютага на 1 сакавіка 1944 г. па забойстве бургамістра Капыльскага раёна [5, арк. 206]. Акрамя таго, ён быў сувязным 27-й брыгады імя В. І. Чапаева Мінскай вобласці.

Успамінаючы ў часопісе «Архівы і справаводства» пра падзеі тых грозных гадоў, кіраўнік падпольнай групы Іван Іванавіч Зіневіч пісаў: «Капыльская падпольная арганізацыя працавала ва ўмовах строгай канспірацыі. Арганізацыя была сапраўдная, моцная, працавала эфектыўна і адрознівалася ад іншых тым, што дзейнічала ў месцах дыслакацыі варожых гарнізонаў, тым, што не мела правалаў». У больш прыватных гутарках падпольшчыкі шчыра дзяліліся: «Калі б мы ў той час не былі ўпэунены ў сабе, таварышах, вернай дружбе, мы б не выжылі!» [6, с. 103-108]. 3 тых часоў Сцяпана Хусейнавіча, Івана Іванавіча і іх баявых паплечнікаў Яўгена Ігнатавіча і Адама Баляслававіча Булат звязвалі шчырыя сяброўскія адносіны. Апрача таго Сцяпана Александровіча і Яўгена Булат збліжала любоў да літаратуры, зачараванасць родным краем.

328 чэрвеня 1944 г. С. Х. Александровіч змагаўся ў складзе атрада імя В.I. Чапаева адзначанай 27-й брыгады імя В. І. Чапаева Мінскай вобласці [7, арк. 52, 270]. У ліпені 1944 г. ён быў накіраваны ў Чырвоную Армію для далейшай барацьбы 3 ворагам. За ўклад у агульную перамогу ўзнагароджваўся ордэнамі Айчыннай вайны II ступені, Славы III ступені, медалямі. 
Пасля вайны ў 1950 г. С.Х. Александровіч зкончыў універсітэт. Выкладаў беларускую мову і літаратуру. 31959 г. па 1963 г. працаваў навуковым супрацоўнікам Інстытута літаратуры імя Янкі Купалы АН БССР, з 1963 г. - дацэнт, з 1974 г. - прафесар Беларускага дзяржаўнага ўніверсітэта, доктар філалагічных навук.

С. Х. Александровіч дэбютаваў у друку ў 1946 годзе. Пісаў навукова-папулярныя i публіцыстычныя нарысы, мастацкія біяграфіі.

У працэсе сваей дзейнасці С. Х. Александровіч даследаваў гісторыю беларускай літаратуры XIX-XX стагоддзяў, развіццё нацыянальнага кнігадрукавання і перыядычнага друку, літаратурныя сувязі.

Значную увагу ён надаваў вывучэнню беларуска-ўкраінскіх і беларуска-польскіх літаратурных кантактаў. У гэтым кантэксте можна адзначыць яго зацікаўленнасць творчасцю Тараса Шаўчэнкі. С. Александровічу належаць артыкулы «Т. Шаўчэнка і Янка Купала», «Тарас Шаўчэнка і Беларусь» (абодва ў 1958 г.) і іншыя. У кнізе «Вальнадумца 3-пад Нясвіжа Аляксандр Незабытоўскі» (1975) С.Александровіч раскрыў малавядомыя падзеі з гісторыі беларуска-польскіх літаратурных і грамадска-палітычных сувязяў у 1840-я гады. Увогуле, можна адзначыць, што С. Х. Александровіч займаўся даследаваннем гісторыі беларускай літаратуры ў міжславянскім, беларуска-балтыйскім i агульнаеўрапейскім гістарычнакультурным кантэксце. У працы «Пуцявіны роднага слова», напісанай ім у 1971 г., прааналізаваў працэс станаўлення новай беларускай літаратуры ў другой палове XIX-пачатку XX ст. паралельна з зараджэннем і развіццём нацыянальнага кнігадрукавання і перыёдыкі. Ён узнавіў цэласную карціну беларускіх перыядычных выданняў і выдавецкіх суполак, таварыстваў, паказаў іх ролю ў ідэйна-мастацкім і жанравым росце айчыннай славеснасці, сталенні нацыянальнага тэатра, музыкі, журналістыкі, у паглыбленым вывучэнні фальклору, этнаграфіi і ўсёй культуры Беларусі [8; 9, с. 29].

Асаблівыя распрацоўкі С. Х. Александровіч прысвяціў жыццю і дзейнасці Ф.Скарыны (По следам Франциска Скорины (Из путешествия в Краков и Прагу) // Бригантина: Сборник рассказов о путешествиях, поисках, открытиях. - М. : Молодая гвардия, 1980. - С. 35-56), а таксама гісторыі народніцкага «Гомана», газетам «Наша доля» і «Наша ніва». Шмат увагі надаваў вывучэнню творчасці Янкі Купалы, яго сувязям 3 польскай літаратурай (Ад роднае зямлі : Аповесць пра маленства і юнацтва Я. Коласа / С. Х. Александровіч. - Мінск : Дзяржвыд БССР, 1962. - 236 с.; На шырокі прастор : Старонкі жыцця Якуба Коласа / С. Х. Александровіч. - Мінск : Мастацкая літаратура, 1972. - 429 с.; Крыжавыя дарогі : Аповесць пра Якуба Коласа / С. Х. Александровіч. - Мінск : Мастацкая літаратура, 1985. - 333 с.).

Вывучаў літаратурна-гістарычную спадчыну Цішкі Гартнага (З.Жылуновіча) «Успаміны пра Цішку Гартнага» (1984). Створаным С. Александровічам літаратурным партрэтам пісьменнікаў П. Багрыма, Ф. Савіча, Янкі Купалы, Якуба Коласа, Змітрака Бядулі, Кузьмы Чорнага i іншым уласцівыя глыбокі гістарызм, жыццёвая праўдзівасць. Ён падрыхтаваў да выдання творчую спадчыну Ф. Багушэвіча, К. Каганца, А. Паўловіча, Цёткі.

C. X. Александровіч дзейсна прычыніўся да ўзбагачэння крыніцазнаўчай i тэксталагічнай базы па гісторыі беларускай літаратуры. Надаваў прынцыповае значэнне метадалогіі даследаванняў, палемізаваў $з$ некаторымі расійскімі і польскімі аўтарамі за іх антыгістарычны падыход да паняццяў «Русь», «рускі», «Літва», «літоўскі», штучнае атаясамліванне з расійскай або літоўскай культурай здабыткаў уласна беларускай культуры, дасягнутых пад гэтымі назвамі ў розныя эпохі [10, с. 552].

С. Х. Александровіч з'яўляецца адным 3 аўтараў «Гісторыі беларускай савецкай літаратуры» (1964) і складальнікаў хрэстаматый «Беларуская літаратура XIX стагоддзя» (1971), «Беларуская літаратура XIX-пачатку XX ст. : хрэстаматыя крытычных матэрыялаў» (1978), «Публицистика белорусских народников : нелегальные издания белорусских народников (1881-1884)» (1983).

У 1984 г. С. Х. Александровіч за свой уклад у развіццё беларускай культуры атрымаў ганаровае званне Заслужанага работніка культуры БССР. 
Памёр беларускі татарын С. Х. Александровіч 1 мая 1986 года. Аднак ён пакінуў пасля сябе каштоўную літаратурную спадчыну, сваёй творчасцю ён значна ўзбагаціў беларускую культуру. Трэба адзначыць, што калегі па працы, сябры, родныя з удзячнасцю і павагай ставяцца да майстра слова, актуалізуюць яго творчасць у межах тэматычных мерапрыемстваў. Так 15 снежня 2016 г. 3 нагоды 95-годдзя 3 дня нараджэння Сцяпана Хусейнавіча Александровіча ў Цэнтральнай навуковай бібліятэцы імя Якуба Коласа Нацыянальнай акадэміі навук Беларусі была арганізавана вечарына «Я заўсёды ішоў сумленнай пуцявінай...», а таксама адбылося адкрыццё выставы «Здабыткі Сцяпана Александровіча». У наступным годзе грамадскасць будзе адзначаць 100-годзе 3 дня нараджэння С. Х. Александровіча.

Такім чынам, прадстаўнік татарска-мусульманскай супольнасці Беларусі Сцяпан Хусейнавіч Александровіч сваёй дзейнасцю прыўнёс неацэнны ўклад у развіццё беларускай культуры, што з'яўляецца ўнікальным i своеасаблівым прыкладам міжкультурнай камунікацыі.

\section{Літаратура}

1. Янушкевіч, Я. Ружы настаўніку (слова на ўспамін пра Сцяпана Александровіча) / Я. Янушкевіч // Байрам. - 1991. - № 4. - С. 17-20.

2. Александровіч, С. Далёкія зарніцы / С. Александровіч. - Мінск, 1967. - 208 с.

3. Александровіч, С. Кнігі і людзі. Даследаванні, архіўныя знаходкі, успаміны, эсэ / С. Александровіч. - Мінск : Маст. літ., 1976. - 207 с.

4. НАРБ. - Ф. 1393. - Воп. 1. - Спр. 40.

5. НАРБ. - Ф. 1405. - Воп. 1. - Спр. 223.

6. Архівы і справаводства. - 2001. - № 3. - С. 103-108.

7. НАРБ. - Ф. 1450. - Воп. 5. - Спр. 165.

8. Александровіч, С. Х. Старонкі братняй дружбы : артыкулы пра літаратурныя сувязі / С. Х. Александровіч. - Мінск : Дзяржвыд БССР, 1960. - 220 с.

9. Биографический справочник. - Мінск: «Белорусская советская энциклопедия» имени Петруся Бровко. - Т. 5. - 1982.

10. Памяць: гісторыка-дакументальная хроніка Мінска. - Мінск: БЕЛТА, 2002. -Кн. 2.

Статья посвящена жизненному и творческому пути Степана Хусейновича Александровича (1921-1986), который, будучи представителем национальной группы местных татар, много сделал для развития белорусской культуры как писатель, критик, литературовед, краевед. В ходе своей деятельности доктор филологических наук, профессор С.X. Александрович исследовал историю белорусской литературы XIX-XX веков, развитие отечественного книгопечатания и периодической печати, литературные связи. Своеобразным примером межкультурной коммуникации является вклад татарина Степана Хусейновича Александровича в развитие белорусской культуры.

The article describes the life and creative activities of Stepan Khuseinovich Aleksandrovich (1921-1986), who, being a representative of the national group of local Tatars, did a lot for the development of Belarusian culture as a writer, critic, literary critic, ethnographer. In the course of his activity, Doctor of Philology, Professor S.Kh. Aleksandrovich studied the history of Belarusian literature in the 19th-20th centuries, the development of domestic printing and periodicals, literary ties. A peculiar example of intercultural communication is the contribution of the Tatar Stepan Khuseinovich Alexandrovich to the development of Belarusian culture. 